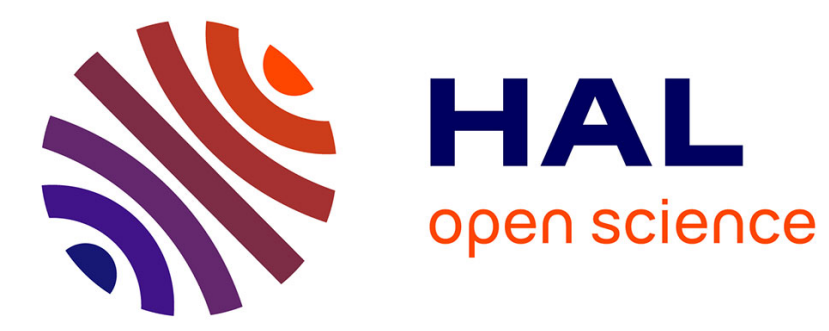

\title{
How can alternative farmland management styles favour local food supply? A case study in the Larzac (France)
}

Adrien Baysse-Lainé, Coline Perrin

\section{To cite this version:}

Adrien Baysse-Lainé, Coline Perrin. How can alternative farmland management styles favour local food supply? A case study in the Larzac (France). Land Use Policy, 2018, Mediterranean Farm \& Land systems Dynamics, 75, pp.746756. 10.1016/j.landusepol.2018.03.012 . hal-01862317

\section{HAL Id: hal-01862317 https://hal.science/hal-01862317}

Submitted on 25 Oct 2018

HAL is a multi-disciplinary open access archive for the deposit and dissemination of scientific research documents, whether they are published or not. The documents may come from teaching and research institutions in France or abroad, or from public or private research centers.
L'archive ouverte pluridisciplinaire HAL, est destinée au dépôt et à la diffusion de documents scientifiques de niveau recherche, publiés ou non, émanant des établissements d'enseignement et de recherche français ou étrangers, des laboratoires publics ou privés. 


\title{
How can alternative farmland management styles favor local food supply? A case study in the Larzac (France)
}

\author{
Land Use Policy, 75:746-756, June 2018, https://doi.org/10.1016/j.landusepol.2018.03.012
}

Adrien Baysse-Lainé ${ }^{* 12}$ \& Coline Perrin ${ }^{2}$

\section{$\underline{\text { Post-print version }}$}

\begin{abstract}
This article seeks to bridge the research gap between farmland tenure management and food provisioning issues in developed countries, by focusing on concentration of agricultural production, access to land and local food supply. We conducted a qualitative study on farmland management in the northern Larzac (France), based on twenty in-depth interviews and document analysis. We distinguish six farmland management styles, i.e. local institutional arrangements encompassing organization of access to the land for farmers and relationships between land rights holders. They emerged or consolidated at three periods: a traditional commons style during the $19^{\text {th }}$ century, three collective styles implemented by farmers' organizations in the early 1980s, and two public styles on the estate of a local authority since 2010. The objective is to show that farmland management styles can serve as tools to foster local food supply, within "space-sharing strategies" based on the creation of farmland estates. In conclusion, we propose three guidelines for public decision-makers seeking, through land policies, to endorse local food provisioning: (i) include civil society organizations dealing with food issues in farmland management committees, (ii) return control of the commons to village councils, (iii) subsidize public acquisitions of land to support local food provisioning projects.
\end{abstract}

Keywords: Access to the land; Commons; Land tenure; Mediterranean highland; Relocalized agro-food system

\section{Introduction}

Local food supply chains in developed countries have rarely been studied from a spatial point of view. Selfa and Quazi (2005) or Kremer and DeLiberty (2011) attempt to identify local food initiatives and map the farmland underpinning them, to bridge the gap between land issues and local food issues. But this gap is not restricted to space: it is also a social, legal and economic gap. Many farmers involved in provisioning local food struggle to access their production factors, particularly land (van der Ploeg et al., 2015). In this paper, our aim is to narrow the knowledge gap between land tenure management issues and local food issues, at a local scale, in the context of the Global North.

To do so, we use a three-pronged approach combining land law and tenure management, land use, and food supply. Some relationships of this framework have already been extensively studied. These include (i) the influence of land ownership and tenure distributions on land use (Luning, 1984; Bruce, 2000; Fay, 2009; Spalding, 2017), (ii) the impact of land use changes on food security and food

\footnotetext{
* corresponding author: abl@posteo.eu

${ }^{1}$ Lumière Lyon 2 University, Rural Studies Laboratory, Lyon, France.

${ }^{2}$ INRA, UMR Innovation, Montpellier, France.
} 
chain organization (Richani, 2012; Millar \& Roots, 2012) or (iii) the relationships between tenure security and food security (Maxwell \& Wiebe, 1999; Merten \& Haller, 2008; Holden \& Ghebru, 2016), tenure security and sustainability of the food system (Baxter, 2013) or land administration and food security (Rockson et al., 2013). These papers view food issues through the lens of food security. We study a less widely explored relationship: the impact of land law and tenure management on land use understood from a food perspective and not only as land-cover data. We subscribe to Borras \& Franco's (2012) view: they interestingly categorize land use according to where the production is sold (for consumption, domestic exchange, export) and their analysis focuses on relationships between such land use changes and ownership changes. This is consistent with our spatial approach to local food supply, since the authors show that the way farmlands are managed can have an impact on the way people are fed.

While all the mentioned papers refer to developing countries, and use global or national scale analysis, very little research has addressed these issues in developed countries and at local scale. To fill this gap, we apply to France a theoretical framework often used to examine natural resource management issues in the Global South, the "bundle of rights" approach (Schlager \& Ostrom, 1992).

We seek to show how land policies can affect the use of the land for local food provisioning, through enhancing access to land for farmers involved in local food chains. We particularly examine land policies dealing with land rights issues. They determine what can be done on specific parcels of land, for how long, and who the rights holders are. This leads us to focus on "space-sharing" land policies, which consist in withdrawing parcels from the land market to build farmland estates, where access to land rights can be managed in an alternative way.

To explore how space-sharing strategies can impact local food supply, we first build a theoretical framework explaining how land rights are managed at a local scale in France. We use it to describe the access to land in a series of farmland estates and we show that several ways of accessing land and dividing land rights into bundles coexist in the country. Little light has been shed on this diversity, because of the predominantly national-scale analysis of land tenure management. Yet, our hypothesis is that farmland tenure and property management are not determined only by national legal and economic evolution: regional or local historical contexts, public policies and stakeholders' relationships also have an impact. It is the theoretical tools to explore and differentiate local management styles that are lacking. To fill this gap, we coin the notion of "farmland management style" (FMS). We define it as the institutional arrangement determining at a local scale the allocation and distribution of land rights. It encompasses two intertwined issues, related to two chronological steps: first the organization of access to the land for farmers, and then the formalized relationships between land rights holders (including the leases).

Building on this theoretical framework, we show how FMSs can be tools to foster local food supply within space-sharing strategies. On a wider scale, this may suggest how land policies could be implemented to address food issues. Indeed, our research question is rooted in a more general concern related to the spaces existing and available in rural areas of developed Mediterranean countries for farms willing to preferentially supply the local market. Can public and collective land management policies drive local food sector development? Are alternative FMSs the most appropriate land measures to tackle food issues at a local scale?

To answer these research questions, we focus on a zone of France's Mediterranean mountains, the northern Larzac, known historically (Terral, 2011) for its variety of FMSs and the large degree of local selling by its farmers. Our study is based on document analysis (maps, leases, public reports, newspapers) and twenty in-depth interviews with farmers and people in charge of managing farmland.

The paper proceeds as follows. The second section provides context data about the Larzac. The third section presents our methodology. The fourth section puts into practice the "farmland management 
style" notion. It explains how the Larzac became a unique region in terms of the high diversity of farmland management. The fifth section examines how sharing strategies differently impacted food provisioning and compares their impact with that of other measures related to access to farmland.

\section{Study area: A Mediterranean highland marked by land use intensification}

We chose to focus on the northern part of the Larzac plateau and its surrounding valleys because this area of Mediterranean France is characterized by a high variety of local FMSs. Covering around $500 \mathrm{~km}^{2}$ (map 1), it is a flat Mediterranean limestone highland (causse) located in the Aveyron département, a sparsely populated rural area. The land is primarily used as rangeland, with some forests and cropland. Extensive sheep breeding is the most common farming industry. The milk is mainly sold to seven local companies that transform it into "Roquefort" cheese. Sold all over France and the world, the Roquefort became the first PDO-labeled cheese in France in 1925 (Frayssignes, 2011). Nevertheless, as reported by an employee of the Chamber of Agriculture, in 2000, in the South of Aveyron, starting farmers were "90\% ewe-milk producers for the Roquefort system [...]. Today, they are only one third in the classical Roquefort system, one third in the short supply chains system" (interview, Feb. 2014) and the last third in other meat breeding systems.

Interestingly, the Larzac is one of the few zones in France where there are more farmers, farms and ploughed land today than fifty years ago. A strong rural exodus impacted the Larzac until the 1950s (Moreau, 1981), leading to land abandonment and scrub and forest encroachment. Since the 1960s,

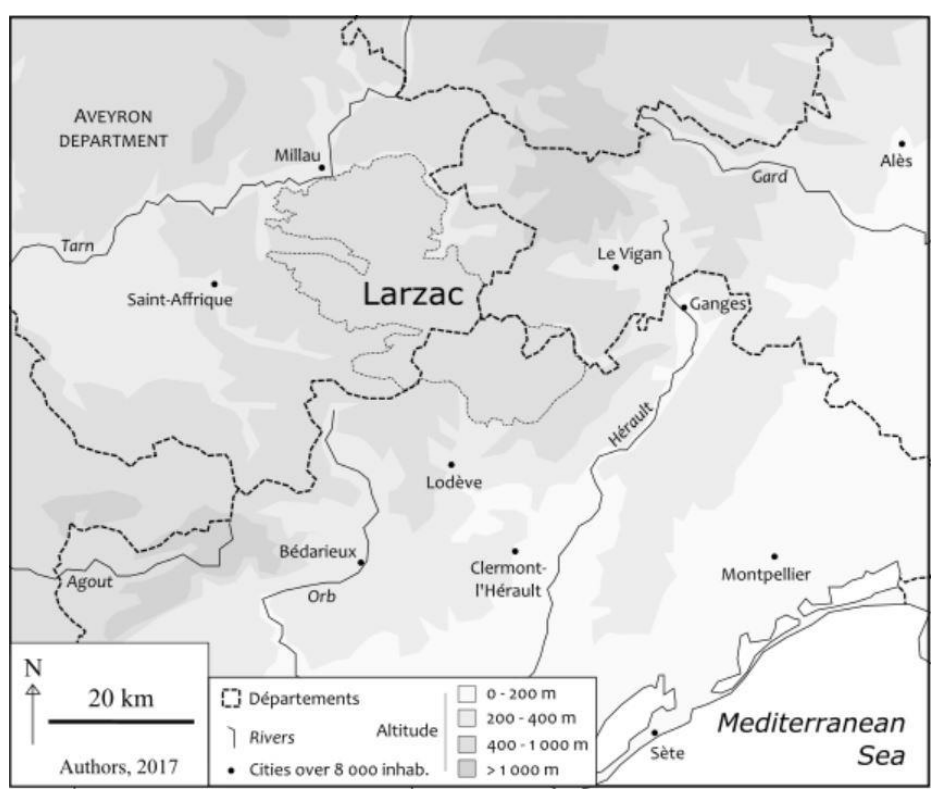

farmers from outside the region have been moving in, creating larger and more modern farms. A land struggle against the extension of a military camp took place in the 1970s: at that time, people migrated to the area to squat and run abandoned farms. This back-to-the-land dynamic is unusual, compared to other Mediterranean and European highlands (Lasanta et al., 2017). Land use further intensified during the 1990s, with pastures being ploughed and abandoned rangeland being reused (Quetier et al., 2005).

Map 1: Location of the study area

\section{Methods and analytical framework}

Our research is based on qualitative fieldwork carried out between 2014 and 2016. First, we conducted twenty semi-structured in-depth interviews with farmers holding land in different management styles and people in charge of alternative and mainstream FMSs. Then, we gathered documents regarding the history of the management styles and how they work, such as lease agreements, 
ownership statements, reports of Council deliberations, articles from local newspapers and institutional magazines. We also collected a set of maps made by the stakeholders and representing the spatial extent of the management styles. To process the information, we transcribed the interviews, integrated their content (and that of the documents) into a common analytical framework (structured around themes like reasons for and conditions of creation, land purchase and/or management strategy, allocation of land rights, internal rules). Finally, we used data collected for a previous study ([reference deleted to maintain the integrity of the review process]) on the local food supply of Millau. All farmers of the study area involved in local food chains were surveyed by short questionnaires, with questions about selling practices and land tenure.

We built a specific analytical framework to interpret this database and information. First, we traced each management style's evolution through a table highlighting changes chronologically. Second, we drew a land rights distribution table for every management style, featuring the stakeholders, their type (public, collective, private), their bundle of rights, the way they obtained the rights and the duration of the rights. This approach is based on Lavigne Delville's (2010) elaboration on Schlager \& Ostrom's (1992) concept of "property rights" to natural resources (table 1). For the latter, the five main types of property rights that apply to farmland are access rights, withdrawal rights, management rights, exclusion rights (i. e. to decide who can use which land) and alienation rights. Lavigne Delville applies this typology to agricultural lands (in Africa), splitting withdrawal rights into extraction rights (e.g. collecting or grazing) and production rights, splitting management rights into planning rights (e.g. reshaping a plot, planting a hedgerow) and internal management rights (i.e. to designate a land use to every plot, including construction rights), splitting alienation rights into transmission rights (i.e. deciding how and to whom rights are transferred when they lose validity) and alienation rights (e.g. transferring definitively the previous rights). In a French context marked by the CAP (Common Agricultural Policy) and its subsidies linked to land, we propose to consider "payment rights" as another subcategory of withdrawal rights. Third, we mapped the spatial extent of the management styles and combined it with the data from the previous study on the farmland used to supply Millau in local food.

\begin{tabular}{|c|c|c|c|}
\hline $\begin{array}{l}\text { Schlager \& Ostrom, } \\
1992 \\
\text { setting: common pool } \\
\text { resources }\end{array}$ & $\begin{array}{l}\text { Lavigne Delville, } 2010 \\
\text { setting: agricultural land in Africa }\end{array}$ & \multicolumn{2}{|c|}{$\begin{array}{l}\text { this study, } 2017 \\
\text { setting: agricultural land in Europe }\end{array}$} \\
\hline access rights & access rights & $1^{\circ}$ access rights & To access or cross a parcel. \\
\hline withdrawal rights & $\begin{array}{l}\text { extraction rights } \\
\text { production rights }\end{array}$ & $\begin{array}{l}2^{\circ} \text { extraction rights } \\
3^{\circ} \text { payment rights } \\
4^{\circ} \text { production rights }\end{array}$ & $\begin{array}{c}\text { To extract existing resources. } \\
\text { To get paid to exercise operational } \\
\text { rights. } \\
\text { To seed, cultivate and harvest plants. }\end{array}$ \\
\hline management rights & $\begin{array}{l}\text { planning rights } \\
\text { internal management rights }\end{array}$ & $\begin{array}{l}5^{\circ} \text { planning rights } \\
6^{\circ} \text { internal management rights }\end{array}$ & $\begin{array}{l}\text { To transform shape, size, relief and/or } \\
\text { land use of a parcel } \\
\text { To define the content and } \\
\text { implementation area of the operational } \\
\text { rights ( } 1 \text { to } 5 \text { ) }\end{array}$ \\
\hline exclusion rights & exclusion/inclusion rights & $7^{\circ}$ exclusion/inclusion rights & $\begin{array}{l}\text { To define the holders of property } \\
\text { rights. }\end{array}$ \\
\hline alienation rights & $\begin{array}{l}\text { transmission rights } \\
\text { alienation rights }\end{array}$ & $\begin{array}{l}8^{\circ} \text { transmission rights } \\
9^{\circ} \text { alienation rights }\end{array}$ & $\begin{array}{c}\text { To control and frame the exercise of } \\
\text { rights (particularly by specifying how } \\
\text { they can be transferred) } \\
\text { To transfer definitively rights }\end{array}$ \\
\hline
\end{tabular}

Table 1: Typologies of farmland property rights 


\section{Results: six co-existing farmland management styles in the Larzac}

Based on this analytical framework, we propose to distinguish six FMSs in the Larzac, ranging from a mainstream private style to five alternative - collective and public - styles. After presenting these styles, we will explore how they have coexisted in the Larzac over time and space since the $19^{\text {th }}$ century.

\subsection{The mainstream management style}

After World War II, a farmland management regime was progressively set up as a national reference in France (Coulomb, 1999; Boinon, 2011). Its main features are (i) private ownership (mainly in the hands of farmers and their family), (ii) the very secure fermage lease agreement (lasting at least nine years and extremely easily renewable) ${ }^{2}$, (iii) control of the farmland market by SAFER (a semipublic body holding a preemptive right on farmlands) and (iv) shared control of access to the land by the farmers' unions and the state services (prefect). Sencébé et al. (2013) characterized it as "management of farmland by and for the farming sector", now gradually giving way to a "management of farmland by the experts". This is due to the recently decreasing influence of majority farmers' unions within SAFER committees, giving way to minority farmers' unions and civil society. As shown in table 2 , the land rights distribution greatly favors farmers and their families, and was described as a "propertylike farm tenure" 3 by Courleux (2011). Private owners still have the right to choose the new farmer if no relative of the previous farmer wishes to farm the land.

Thus, in our study area, the mainstream management style is private but supervised by SAFER, the farmers' unions and the state agricultural services. The fermage is now the major form of tenure: to access land, farmers (predominantly those already running a farm) approach landowners (usually neighboring retired farmers or relatives) and reach an agreement. Farm transfers take place either within the kinship group or through SAFER (working in these cases as a real estate agency). Social reputation and mutual acquaintances within the agricultural community strongly impact the deals, which does not make it easy for newcomers to take over or create farms. As a representative of the Peasants' Confederation $^{4}$ put it, when a SAFER committee has to decide to whom a farm without heir should be sold, "typically, the majority farmers' union would say 'the farm is not viable, the largest neighbor should take it over'. And we [the Peasants' Confederation] would support an aspiring farmer looking for land - if there is one -, or advise splitting up the farm between the smallest neighboring farms" (interview, Jan. 2016).

This FMS opened a wide window of opportunity for mainstream farming organizations to develop the farming style they considered the most suitable to develop agriculture. As defined by van der Ploeg et al. (2009), a farming style is "a coherent set of strategic notions about the way in which farming should be practiced [... which create] an internally consistent mode of farming [... legitimated as a] development pattern". As such, the large, specialized and quite intensive ewe-breeding farms

\footnotetext{
2 This lease agreement is the default option for rented farmland in France. It was created in 1946 to secure access to land for farmers, at a time when family agriculture was extremely dominant. The main objective was to discourage farmers from investing in land, and to encourage them to purchase other production factors (tractors). Farmers can transfer their fermage to their close relatives (sons, grandsons, nephews, brothers and sisters, parents, uncles and aunts) and they hold a preemptive right on land.

${ }^{3}$ Our own translation, from "quasi-propriété culturale"

${ }^{4}$ A minority farmers' union belonging to La Via Campesina, which represents alternative farmers.
} 
supplying the Roquefort industry with milk became the locally dominant farms in our study area. According to a SAFER employee, "the medium size of farm coming on the market is 100 ha [specialized in ewe-milk] and costs $700000 €$ " (interview, Jan. 2016). Consequently, the food chains are structured by the Roquefort industry towards the national $(80 \%)$ and the export $(20 \%)$ markets.

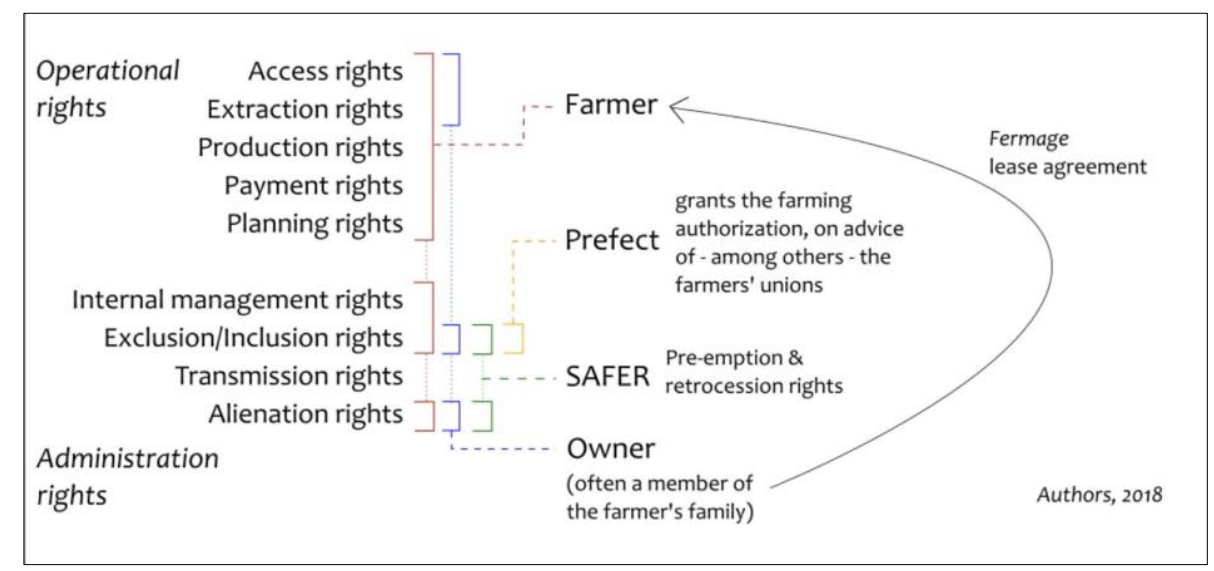

Table 2: Simplified organization of the mainstream management style.

\subsection{Two collective styles}

Aside from the mainstream style, two collective management styles operated by farmers' organizations were created after a local land struggle. This struggle took place in the Larzac from 1971 to 1981, as part of the "counter-cultures" emerging in the aftermath of May 1968's nationwide civil unrest. The triggering point was the government's decision to expand a military camp on land considered unsuitable for agricultural modernization. More than a hundred farmers fought back, supported by committees throughout the country. In ten years, the government acquired only 6400 ha of the 14000 ha targeted. Opponents bought tracts of land within the planned extension area, first to slow down the process, then to secure agricultural tenure for newcomers. They now hold 1500 ha of land, managed by a civil organization called SC GFA Larzac ${ }^{5}$ (table 3). The government finally abandoned the expansion project and created another civil organization, $\mathrm{SCTL}^{6}$, to manage the land it had bought (table 4). On both types of land (State-owned and SC GFA Larzac-owned), farmers who became tenants took an active part in or supported the struggle. Moreover, these new farmers started to develop collective practices. Many of them created collective farming groups $\left(\mathrm{GAEC}^{7}\right)$ and equipment-sharing cooperatives $\left(\mathrm{CUMA}^{8}\right)$ (Terral, 2011). Around farmer-activist José Bové, the Larzac became one of the fiefdoms of the Peasants' Confederation.

The major difference from the mainstream management style is that the 56 tenant farmers control all or nearly all the bundle of rights, partly as farmers and partly as members of the civil organizations SCTL and SC GFA Larzac. As farmers, they have operational rights. As members of the farmers' organizations, they elect a Management Board to which the administration rights (and some planning rights) are delegated. When farmers retire, they must leave their farm and house (career-long lease). The Management Board calls for applications and chooses their successors by consensus, focusing on "matching the project with the immediate environment, the neighbors, $[\ldots]$ and sometimes

\footnotetext{
${ }^{5}$ Société civile Gestion foncière agricole du Larzac, Civil-law company for farmland management of the Larzac

${ }^{6}$ Société Civile des Terres du Larzac, Civil-law company for Larzac land

${ }^{7}$ Groupement agricole d'exploitation en commun

${ }^{8}$ Coopérative d'utilisation du matériel agricole
} 
[asking] the opinion of the hamlet residents" (interview with two SCTL managers, Jan. 2016). Compared to the mainstream style, land is allocated through a more open process. According to a manager, this is due to the fact that "we don't come from here, we came from outside, to join the struggle. When you want to tackle land tenure issues, it is far better not to be a native: if you have been here for generations, you are bogged down in a lot of problems." The only difference between the two collective management styles concerns security of tenure, which is higher for SC GFA Larzac land. In the case of SCTL, the French state maintains alienation rights, through an emphyteutic lease ending in 2083.

No written formal criteria guide the selection of new farmers, but some "red lines" exist: the two managers mentioned for instance that an intensive husbandry project would never be accepted. Altogether, the selection process resembles co-opting. First, the calls for application are published only in the "fairly activist press [because] it draws enough candidates" (interview, Jan. 2016), which preselects aspiring farmers who lean ideologically towards agroecological peasant farming. Second, consensus is required among the Board: as many members are farmers who opposed the military camp extension, they select like-minded newcomers willing to commit to the collective organization. One SCTL manager stated «our goal is to ensure that an alternative model with a strong agricultural basis keeps going over the long term » (interview, Jan. 2016). Therefore, the already locally dominant peasant and small-scale farming (the farming style advocated by La Via Campesina) is de facto strengthened by this FMS.

Along these lines, some farmers decided to quit the Roquefort system of marketing and to sell directly to consumers ewe products they transform themselves or through a small cooperative (various non-Roquefort cheeses, yogurt, lamb meat) and other foodstuffs they produce (bread, honey, liquors). In the 1970s and 1980s, they supplied supporting committees of the struggle all over the country. Over time, re-localized collective chains were created: in the 1980s to supply Montpellier's open-air markets and in the 2000s to supply Millau, in a collective producers' shop. To this day, and depending on the villages, up to $15 \%$ of the land is used to provision Millau (Baysse-Lainé \& Perrin, 2017).

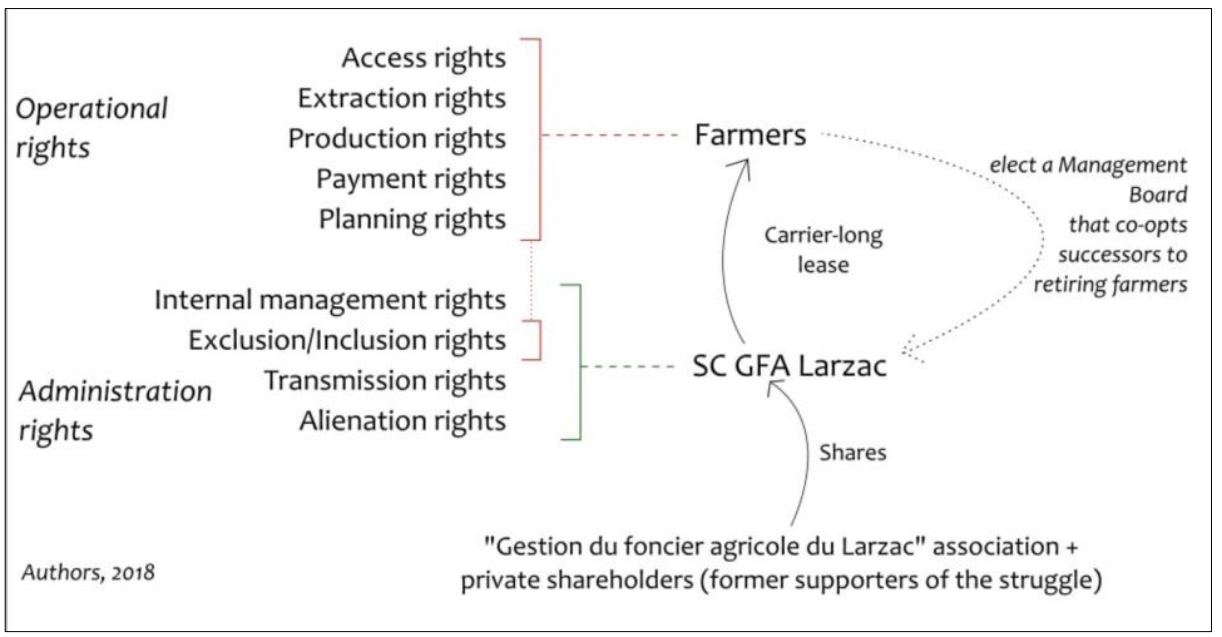

Table 3: Organization of the SC GFA Larzac collective management style 


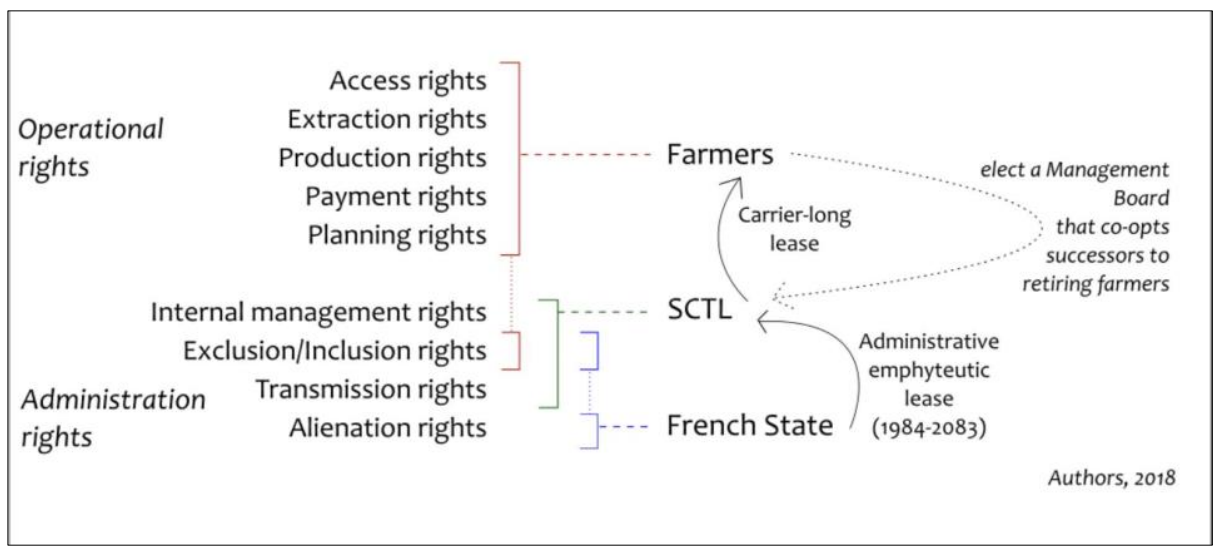

Table 4: Organization of the SCTL collective management style

\subsection{The disappearance of the commons style}

Management of the traditional commons is either mainstream style or informal collective control by farmers. When the French revolutionary government "invented" the absolute private ownership model (Pisani, 1977), it faced a barrier: a large share of the land was commons (communaux). However, over the $19^{\text {th }}$ century, most of these commons were allocated to local dwellers or sold (Vivier, 1998): much of the land remaining commons had, as in other European countries, "low agricultural productivity, being located in remote, upland areas" (Brown, 2006). Thus, in the Larzac, thousands of hectares of rangeland have remained commons, according to the people surveyed. Village Councils usually lease the land to farmers, not based on any particular policy. One Council (at La Couvertoirade) is seeking to take back control of its commons, as explained by the mayor: "We are disturbed by the unfairness [of the land distribution ...]. At some point, it would be good to find another way of sharing out the commons. [...] We have no means to force the farmers [to do it...] because the fermage is transmissible from father to son" (interview, Jan. 2016).

The management of the commons of the village of Sainte-Eulalie de Cernon evolved differently, towards collective control of the commons by its users. Until the 1970s, 1700 ha of commons were allocated every three years to the residents of the village, who leased them to farmers. This practice was illegal and inefficient (due to the extensive parceling out of the land). It was therefore stopped, and an association of landowners ( $\mathrm{AFP}^{9}$ ) was created in 1980 on 1880 ha of commons (and some private land), to pool development work, such as tracks, ponds, enclosures or cattle grids. De jure, AFPs usually hold extended property rights, but de facto, the AFP at Sainte-Eulalie de Cernon is run collectively by farmers. Since the Village Council is the majority owner (with $91 \%$ of the land), and as the mayor and some village councilors at the time were farmers, they monopolized the seats on the AFP Board. This informal situation persists (table 5), even though farmers are no longer members of the Village Council, because the new councilors are not interested, as the AFP president states: "we would like to keep this dynamic going and our organization involved, but we are open and the new mayor understood that. Actually, they didn't understand anything, and we had to explain things to them" (interview, Jan. 2016). In contrast to the two other collective styles, the AFP uses classic fermage lease agreements. Consequently, this third collective style is principally a tool for a closed group of farmers (unchanged since creation) to secure their access to the land.

\footnotetext{
${ }^{9}$ Association Foncière Pastorale, Pastoral Land Association
} 
As the land is rangeland, the dominant farming style is fairly extensive livestock farming ( $85 \%$ ovine, $15 \%$ bovine). Animals are sold to slaughterhouses or cooperative selling associations in the region, with nation-wide supply chains. Being less involved in local development issues and countercultures than the SCTL and SC GFA Larzac farmers, the AFP farmers did not set up any local food chains or diversification of production.

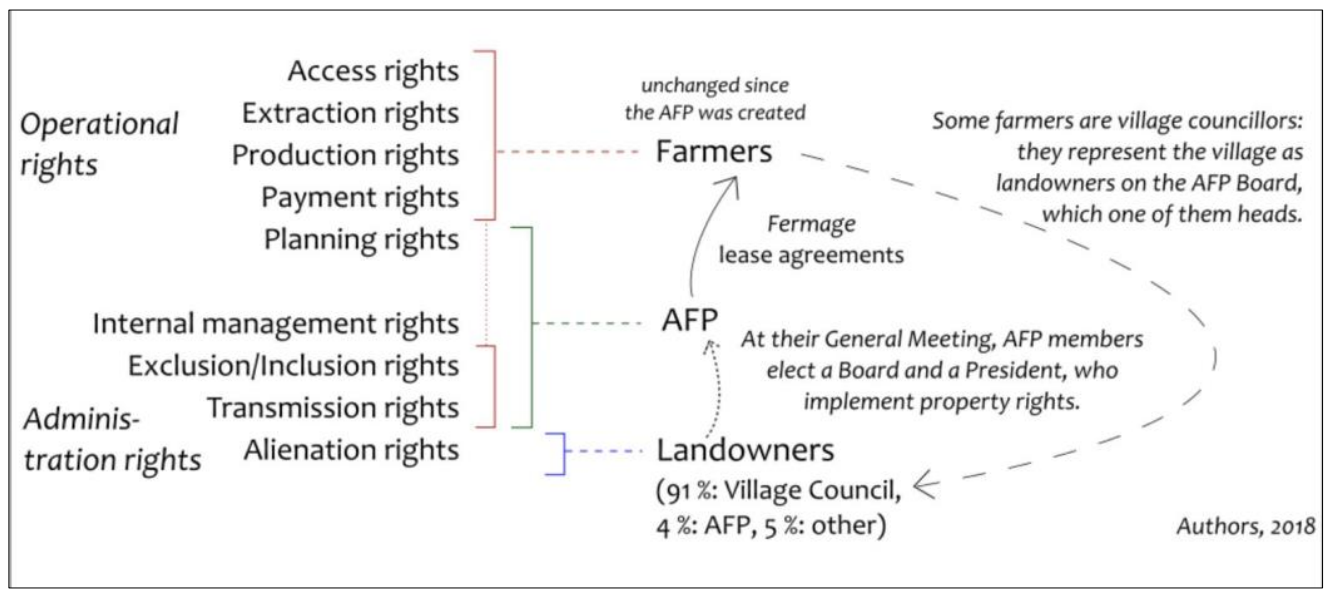

Table 5: Organization of the AFP collective management style

\section{$\underline{4.4 \text { Public management styles }}$}

Finally, two public management styles are operated by an urban local authority on a small estate. From the mid-2000s to the mid-2010s, the "Millau Grands Causses" (30 000 inhabitants) local authority has been trying "to protect and purchase farmland to develop market gardening, of course organic" (interview with its vice-president, Feb. 2014). This is strongly linked to the aim of provisioning the city school canteens with local products. Local agriculture is mainly oriented towards dairy and meat products, and councilors considered that there was insufficient vegetable production. The narrow valley floors, on alluvial and irrigable soils, were targeted by this purchase strategy. But "livestock farmers have always positioned themselves on this land, to cultivate maize or to set up pastures" reported a farmers' union representative (interview, Jan. 2016). Purchasing land is thus difficult, and only 7 ha have been acquired since 2005, split into two groups of plots.

The two groups of plots are managed in slightly different styles, but both styles involve strong commitment to local vegetable supply. Access to the land is granted directly, without calls for applications. The first group of plots was bought in 2005 to protect a water catchment area. Restrictions on use were imposed by the prefect and the plots had to be accessible to the public. This group of plots remained uncultivated until 2010, when a non-profit organization promoting market gardening ("Chayran Garden") occupied and reclaimed it, arguing that it could be used to feed local people. Following this short action, inspired by the 1970s Larzac struggle, "Chayran Garden" obtained the right to cultivate the land, but with a non-secure year-to-year lease agreement, and a commitment to produce only organic vegetables (table 6). Building on this, the local authority decided to purchase more land to develop short vegetable supply chains: 2 ha were acquired in 2014. On the second group of plots, a fermage lease agreement was signed with an aspiring organic market gardener: the distribution of bundles of rights is similar to that used in the mainstream style (table 7).

From the outset, the estate strategy of the local authority has been closely linked to a specific farming style (organic market gardening). Both farms sell their entire production in Millau, through a wide range of food chains: farmers' collective shop, organic food baskets, school canteens, open-air 
market. Thus, the specific management style appears to be less important to the local authority than the farming style.

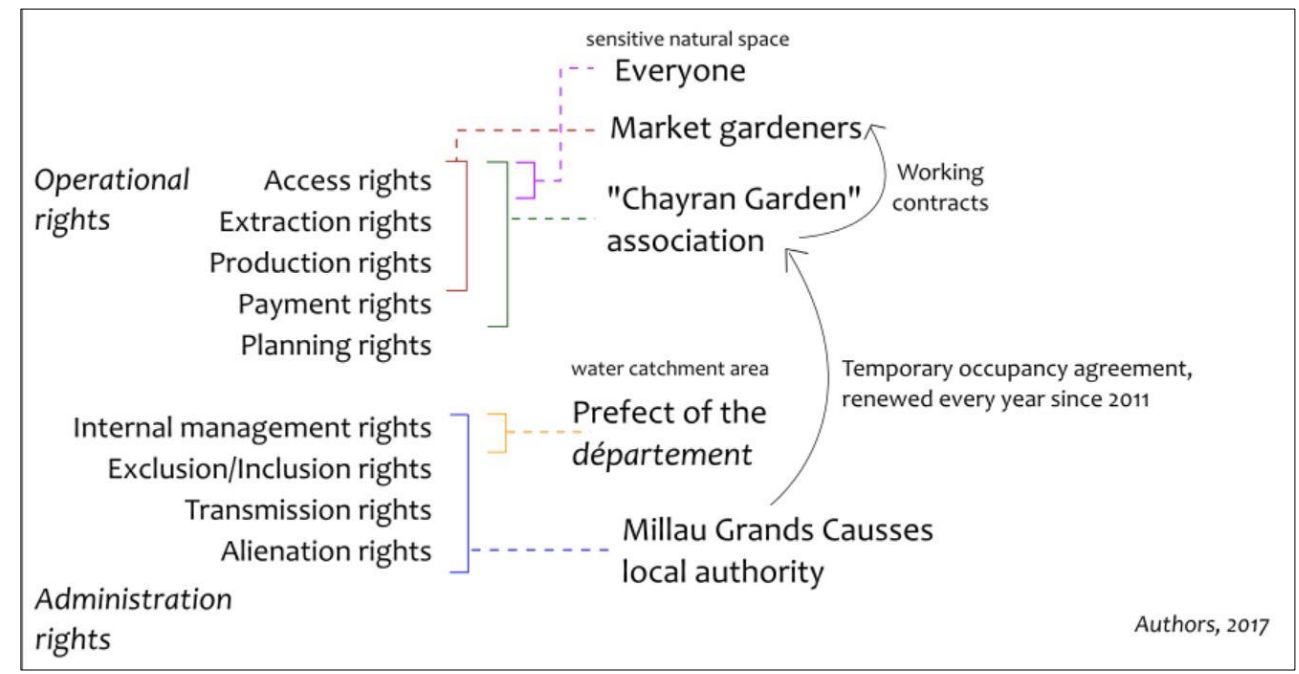

Table 6: Management style on the first group of plots owned by the Millau Grands Causses local authority (5 ha)

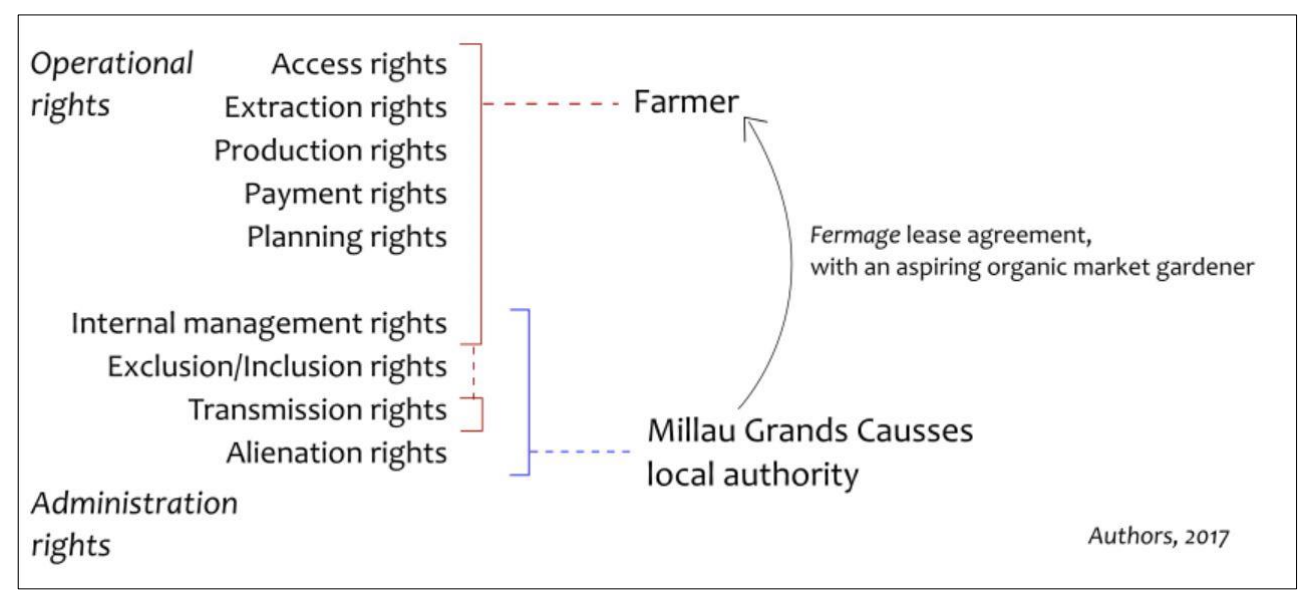

Table 7: Management style on the second group of plots owned by the Millau Grands Causses local authority (2 ha)

\subsection{Farmland management styles over time and space}

Alternative FMSs progressively extended, as they emerged over a three-stage history. The five alternative styles we reviewed in sections 4.2., 4.3. and 4.4. have coexisted over time and space since the $19^{\text {th }}$ century. First, they have very diverse spatial extents. Map 2 shows that collective styles are particularly widespread, covering 9780 ha: 6400 ha for SCTL, 1880 ha for the AFP and 1500 ha for SC GFA Larzac. In comparison, public styles cover a very limited area: only 7 ha. However, the land where collective styles operate is on the Larzac plateau rangeland, whereas public styles cover land on the fertile valley floors, where land prices are ten times higher. 


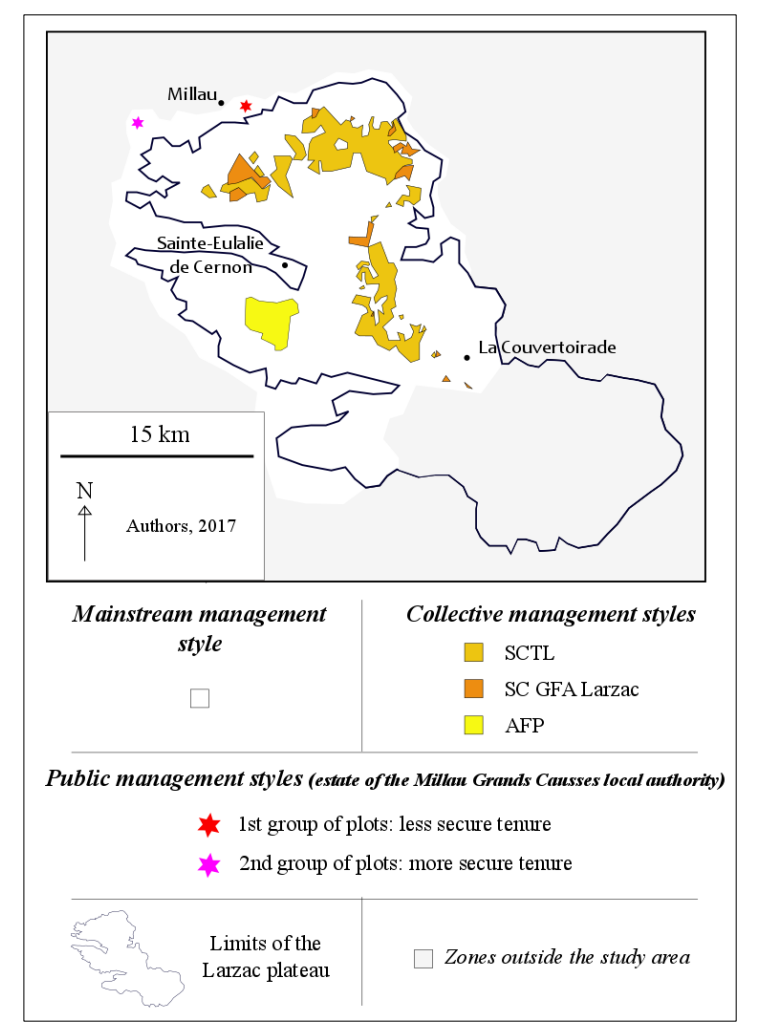

Map 2: Spatial extent of management styles in the northern Larzac

The difference in the areas covered by each style echoes their different histories. Alternative FMSs emerged in the Larzac during three periods. They were shaped by the contemporaneous land policy views and "land management regimes", described by Rudbeck Jepsen et al. (2015) as the combination of institutional and technical drivers of agricultural land use change. To trace the emergence of alternative styles, and to identify the major stakeholders in these processes, we drew up chronological table 8 .

- First, during the $19^{\text {th }}$ century, in keeping with the "Innovations \& Rights" and "Intensification" regimes (Rudbeck Jepsen et al., 2015), and the consolidation of the private land ownership model, the commons were largely privatized, particularly those most suitable for agriculture. The commons land management style had for centuries been dominant in the Larzac. It became a marginal, alternative, enduring management style, with the progressive rise of the mainstream style under the ruling "Industrialization" land management regime (ibid.) after 1945.

- Second, during the 1970s and early 1980s, a period influenced by collective ways of production and life, the three collective styles emerged. Their common feature is extensive control of property rights by farmers' organizations. Two of them (SCTL and SC GFA Larzac) are based on large land acquisitions made during the Larzac camp land struggle. The third is the AFP on the commons of Sainte-Eulalie de Cernon. With SCTL and SC GFA Larzac, new farmers are co-opted on the basis of the project they plan to implement on the farm - including the farming style - whereas the AFP is used by village livestock farmers to secure their access to rangeland. In parallel, the commons management style disappeared, merging into the mainstream style through the spread of fermage lease agreements.

- Third, during the 2000s and early 2010s, influenced by the sustainable development context and the revival of civil society's interest in farmland (Rudbeck Jepsen's "Environmental awareness" land management regime), the Millau Grands Causses local authority began to rent out public land to provision the city with organic vegetables. The management of its two groups of plots differs mostly in 
terms of farmers' precarity of tenure. In the same period, the mainstream style slightly changed, from management "by and for the farming sector", into "management by experts" (Sencébé et al., 2013). This evolution did not affect the five alternative styles.

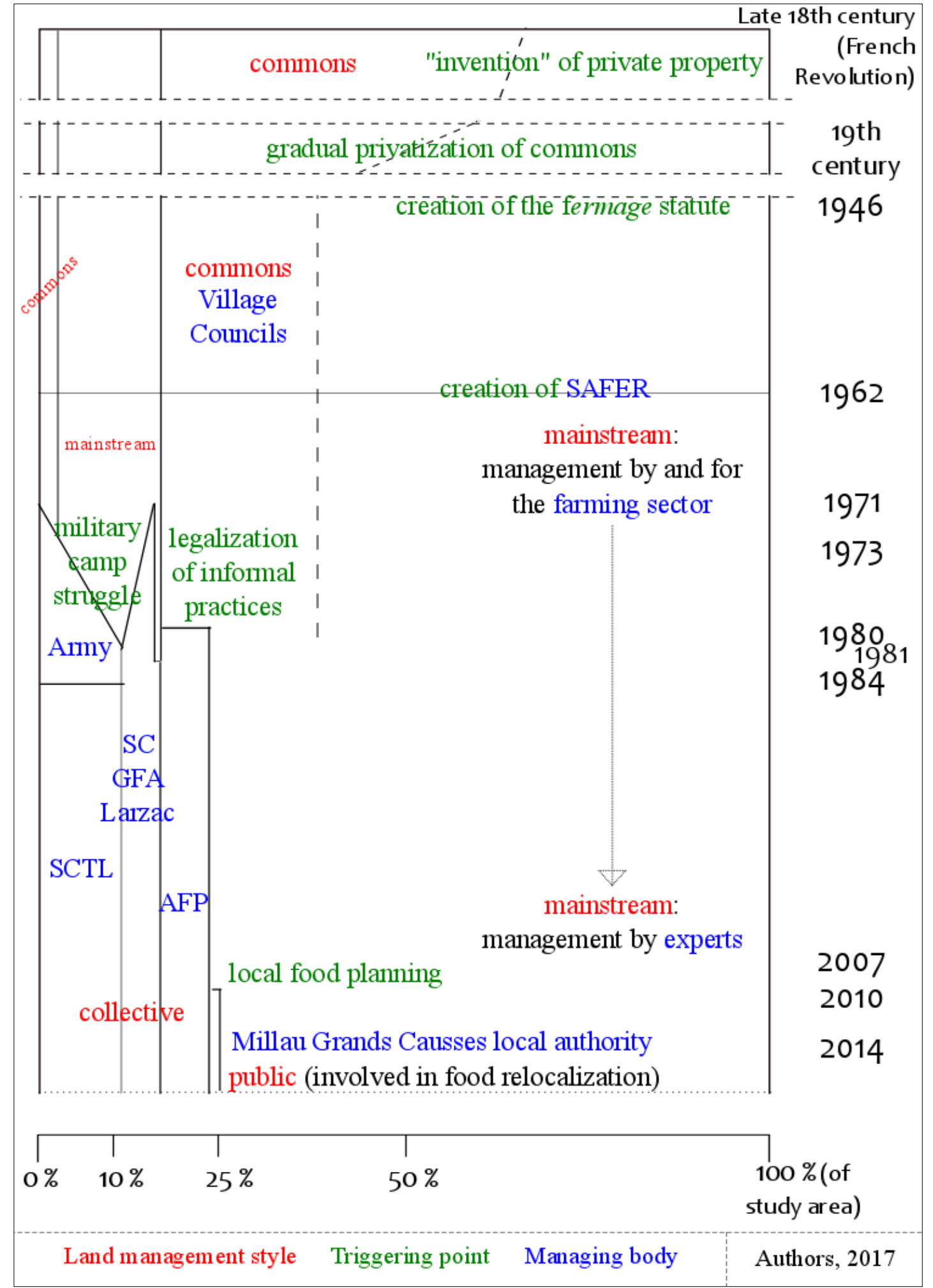

Table 8: Emergence and proportional coverage of different management styles in the Larzac 
This section shows how the notion of FMS helps reveal - at a very local scale and from a spatial point of view - special features of land tenure and management issues. It offers insights into how farmland management can differ from one estate to another, even under the same national jurisdiction.

\section{Discussion: to share and not to share spaces to foster local food}

In this section, we examine how FMSs can be direct tools to shape food provisioning patterns, but also how they can have unintended consequences on the configuration of supply chains. Indeed, FMSs appeared in the last section as the expression of various space-sharing strategies, based on farmland estates. To better assess how they qualitatively transform land access and food provisioning patterns, we compare their effects with other measures related to access to farmland within "nonsharing" strategies.

\section{$\underline{\text { 5.1. Farmland management styles and local food supply }}$}

Land estate strategies can impact food provisioning patterns through a dominant farming style. Table 9 summarizes the main features of each FMS and of its dominant farming style. Indeed, as explained in subsections 4.1. to 4.4., one farming style tends to dominate in each FMS's space. Other, minority, farming styles may exist. For instance, some of the first SCTL farmers have continued to produce ewe-milk for Roquefort (as sketched in subsection 4.2.) and some farmers run small-scale and peasant farming farms in the mainstream FMS areas (as will be presented in section 5.2.). Nevertheless, these examples remain niches in estates dominated by another farming style. This domination appears to be strongly linked to the land management style: by constituting estates, farmland managers are able to foster one specific farming style, making it a criterion of access to land, whether official or not. All these styles include features related to food provisioning. Tenure itself thus appears less important to understand how land issues and food issues are intertwined than the implications of the tenure and the projects depending on it.

First, FMSs can be tools to directly foster local food supply, when used within a space-sharing strategy. For instance, in the Millau Grands Causses public estate, land rights are allocated to farmers whose selling scheme is local from the outset. It is noteworthy that this happens in the most urban area of our sample, where, as in many cities, local food supply is becoming an issue. By contrast, for the Village Councils of the Larzac, local food supply is not yet a major concern. Moreover, there is not enough time to implement such projects: most village councilors are busy with their main professional (non-political) activity and rely on a very reduced public administration.

Second, FMSs can foster local food supply without being implemented specifically to achieve that goal. Here, the way the dominant farming style incorporates food issues is crucial. This happens particularly in SCTL and SC GFA Larzac estates, created before satisfying demand for local food became an issue. However, many farmers have been involved in local food chains for decades, as part of their small-scale and peasant farming style. Due to the specific organization of their FMS, they have the power to co-opt all new farmers. Most of newcomers are therefore also involved in local food chains. The contribution of SCTL and SC GFA Larzac's FMSs to the re-localization of the agri-food system was unplanned, but is significant. According to our previous survey on the local food chains within these estates, the products of 94 ha of ploughed land and 560 ha of rangeland are sold in Millau, whereas 
within the mainstream-managed part of the Larzac (which is larger), the products of only 33 ha of ploughed land and 90 ha of rangeland are sold in Millau.

Finally, it appears that two farming styles particularly favour local (and regional) food chains: the organic market gardening and the small-scale and peasant farming. Only two collective (SCTL and SC GFA Larzac-run) and two public FMSs promote these farming styles. They remain alternative pathways to the conventional agricultural and food systems, which support a dominant conventional farming style and industrial, nationwide and/or global food provisioning patterns. Therefore, in this stalled context, FMSs can be tools to promote local food chains as they provide farmland mangers with the opportunity and means to favour local food supply (as the Millau Grands Causses authority did) or to promote a farming style favourable to local food supply (as SCTL and SC GFA Larzac did).

\begin{tabular}{|c|c|c|c|c|}
\hline $\begin{array}{l}\text { Management } \\
\text { style }\end{array}$ & Access to the land & $\begin{array}{c}\text { Relationships between } \\
\text { owners and users }\end{array}$ & $\begin{array}{c}\text { Dominant } \\
\text { farming style }\end{array}$ & $\begin{array}{l}\text { Dominant food } \\
\text { chains and local } \\
\text { provisioning }\end{array}$ \\
\hline Mainstream & $\begin{array}{c}\text { Agreement } \\
\text { between owner and } \\
\text { aspiring farmer }\end{array}$ & $\begin{array}{c}\text { Fermage lease } \\
\text { agreements (highly } \\
\text { secure and transmissible } \\
\text { inside the family) }\end{array}$ & $\begin{array}{l}\text { Large ewe-breeding } \\
\text { farms supplying } \\
\text { Roquefort } \\
\text { producers with } \\
\text { milk }\end{array}$ & $\begin{array}{c}\text { Nationwide and } \\
\text { export-oriented } \\
\text { chains. }\end{array}$ \\
\hline $\begin{array}{l}\text { Collective, by } \\
\text { SC GFA Larzac }\end{array}$ & \multirow{2}{*}{$\begin{array}{l}\text { Decision by } \\
\text { consensus of the } \\
\text { Management } \\
\text { Board (formed by } \\
\text { farmers), after a } \\
\text { call for } \\
\text { applications }\end{array}$} & $\begin{array}{l}\text { Career-long lease } \\
\text { agreements (highly } \\
\text { secure but not } \\
\text { transmissible) }\end{array}$ & \multirow{2}{*}{$\begin{array}{l}\text { Small-scale and } \\
\text { peasant farming }\end{array}$} & \multirow{2}{*}{$\begin{array}{l}\text { Mostly short supply } \\
\text { chains, towards } \\
\text { local (Millau) and } \\
\text { regional } \\
\text { (Montpellier) } \\
\text { markets. The } \\
\text { remaining are } \\
\text { Roquefort farms. }\end{array}$} \\
\hline $\begin{array}{c}\text { Collective, by } \\
\text { SCTL }\end{array}$ & & $\begin{array}{c}\text { Career-long lease } \\
\text { agreements, only until } \\
2083\end{array}$ & & \\
\hline $\begin{array}{c}\text { Collective, by } \\
\text { the AFP at } \\
\text { Sainte-Eulalie de } \\
\text { Cernon }\end{array}$ & $\begin{array}{l}\text { Decision of the } \\
\text { AFP Council } \\
\text { (formed by } \\
\text { farmers), without } \\
\text { calls for } \\
\text { applications }\end{array}$ & $\begin{array}{c}\text { Fermage lease } \\
\text { agreements }\end{array}$ & $\begin{array}{l}\text { Livestock farming } \\
\text { (because land is } \\
\text { rangeland) }\end{array}$ & Nationwide chains. \\
\hline $\begin{array}{l}\text { Public, on the } \\
\text { first group of } \\
\text { plots of the } \\
\text { Millau Grands } \\
\text { Causses local } \\
\text { authority }\end{array}$ & $\begin{array}{l}\text { Ratification of land } \\
\text { occupation by the } \\
\text { local authority }\end{array}$ & $\begin{array}{l}\text { Year-to-year lease } \\
\text { agreements }\end{array}$ & \multirow{2}{*}{$\begin{array}{l}\text { Organic market } \\
\text { gardening }\end{array}$} & \multirow{2}{*}{$\begin{array}{l}\text { Local selling: } \\
\text { producers' shop, } \\
\text { school canteens, } \\
\text { open-air market, } \\
\text { vegetable boxes. }\end{array}$} \\
\hline $\begin{array}{l}\text { Public, on the } \\
\text { second group of } \\
\text { plots of the } \\
\text { Millau Grands } \\
\text { Causses local } \\
\text { authority }\end{array}$ & $\begin{array}{l}\text { Decision of the } \\
\text { local authority, } \\
\text { without calls for } \\
\text { applications }\end{array}$ & $\begin{array}{c}\text { Fermage lease } \\
\text { agreements }\end{array}$ & & \\
\hline
\end{tabular}

Table 9: Relations between FMSs, dominant farming styles and food provision

$\underline{5.2 \text { Space-sharing and non-sharing strategies helping alternative farmers gain access to land }}$ 
FMSs are the expression of "space-sharing" strategies, side by side with "non-sharing" strategies. Alternative FMSs are one of two land strategies used to promote the relocalized agri-food model: as Clément and Soulard (2016) emphasize, "public bodies and land management associations [can] acquire land or facilitate access to the land for aspiring farmers" ${ }^{10}$. The first strategy we studied consists in creating specialist spaces: the agricultural space is shared among various FMSs. A new FMS removes land from the mainstream management style so as to manage it with another, alternative, aim. The second strategy consists in setting up a network of people, tools and information to help alternative farmers gain access to the land on the mainstream land market. In this case, the land to be used for food provisioning is determined a posteriori, and its use appears less secure.

The first, "space-sharing", strategy consists in taking control of land for a long period and managing it autonomously, by stepping outside the individual private land ownership model. For instance, the SCTL is going to manage land until 2083 - or even longer if the French state renews the emphyteutic lease. Such a long-term perspective means that new farmers involved in small-scale peasant farming will have the opportunity until the early 2040s to start a business there throughout their career. In the case of SC GFA Larzac, no time limit is foreseen, as the alienation rights belong to an association and individuals supporting the Larzac experiment. Contrastingly, for the land managed by the local authority, the time horizon is mainly shaped by the local elections every 6 years. Interestingly, the last change of majority party on Millau Grands Causses council (from center-left to center-right) stopped the land acquisition process, but did not call into question the already-running public farmland estate. In all these examples, since land is no longer sold, legal control by SAFER is avoided. Therefore, on large tracts of the area under their supervision, employees of SAFER never visit parcels or meet farmers and land managers. To one of them, who even found it hard to situate the SCTL estate during our interview, "there is no market in the Larzac. People have lands, but never release them" (interview, Feb. 2016). To another, "in the Larzac, there are few sales: the SCTL handles things" (interview, Jan. 2016). These quotations show a clear farmland divide between the market and the non-private estates.

The strategy of sharing spaces by de-privatization is not new at the global scale, even though it remains marginal. It echoes a long tradition of exiting the private land market through socialization - be it fostered by the state (nationalization) or by other public bodies (e.g. municipalization) - or collectivization. This occurred mainly in socialist countries, with the sovkhoz and kolkhoz experiences (Bauerkämper \& Iordachi, 2014). In capitalist countries, many non-private land ownership models were invented. In the USA, the Land Trusts' movement (Wright, 1992; Souder \& Fairfaw, 1996) aims at securing land use over long periods of time, through either full ownership or simply the purchase of development rights. In England and Wales, County Council Farms have made it easier for new entrants to agriculture to access land since the 1920s (Cooper, 2013). We have a similar experience in our sample with the second group of public plots rented by Millau Grands Causses under a classic lease agreement. In Scotland, community buy-out of large (absentee) landlords' estates by their farmers is allowed under a 2003 land reform (Hoffman, 2013). This collective management by a community echoes the SCTL and SC GFA Larzac experiences.

In France, this de-privatization strategy was notably embodied in the land reform proposed by the Left Alliance led by F. Mitterrand in the 1981 presidential elections. As framed by former Minister of Agriculture Pisani (1977), the state would have created a new land tax to purchase every tract of land put on the market. The land would have been managed by public district-scale land trusts: Offices Fonciers. In the end, this reform was abandoned: in France, farmland is still mainly privately-owned. There is no equivalent of the large-scale land trusts existing, for example, in the USA. Nevertheless, SCTL can be considered as a prototype of the Office Foncier, apart from the fact that it is managed by

\footnotetext{
${ }^{10}$ Our own translation, from « la collectivité publique ou des associations de gestion du foncier [peuvent] acquérir la terre ou faciliter son accès aux candidats à l'installation ». Emphasis added.
} 
the farmers themselves, and not by a citizens' body. Indeed, after Mitterrand's election, the farmers who had opposed the military camp extension decided to transform the Larzac into a "laboratory for farmland tenure management" ${ }^{\prime 1}$.

The development of this strategy continues in France with the civic land investment company and endowment land trust Terre de Liens ${ }^{12}$ (Le Monnier, 2013), which is deeply rooted in the Offices Fonciers and SCTL tradition. It holds more than 3500 ha of land throughout the country and promotes small-scale, organic, relocalized and peasant farming. It is also the main advocate of the recognition of farmland as a common resource in France (Pluvinage et al., 2013; Pibou, 2017). In the current debates about farmland's status and missions, the initiatives taken in the Larzac since the 1970s are widely cited as examples to follow, for instance among the supporters of the struggle against the airport planned at Notre-Dame des Landes, in western France (Rialland-Juin, 2016). A member of the Peasants' Confederation summarized this opinion: "today, really the only place in France where farmland is controlled is the Larzac, and there are no farms disappearing. But of course it's a kind of communist experiment" (interview, Jan. 2016). Indeed, in a context marked by increasing farmland concentration, this exit from the land market can trigger conflicts between agricultural holdings and farming sectors (van der Ploeg et al., 2015): it raises power issues related to the control and allocation of agricultural spaces.

The second, "non space-sharing", strategy relies on other stakeholders, acting within the marketdriven mainstream management style. Among them are the ADEAR ${ }^{13}$, associations coaching aspiring farmers - particularly those not from a farming background -, on how to fine-tune their farming project, find land to settle or obtain farming authorization. Created by the local Peasants' Confederation, the ADEAR of Aveyron département targets projects for new "small-scale farms, environment-friendly and oriented towards the local economy", with the aim of "setting up a more input-independent and jobcreating farming sector, producing high-quality goods and services" 14 . According to the employees we interviewed, around a hundred aspiring farmers every year in the Aveyron département participate in collective training courses, individual coaching sessions, networking meetings (particularly with farmers' union representatives, soon-to-retire farmers or local councilors), mentorship or internship with farmers. Some training courses specifically address ways of gaining access to land, providing knowledge (about the legal and social organization of access to land) and skills (focusing on negotiation, financial and planning aspects). Furthermore, a weekly "Farmland newsletter" contains classified ads for parcels of farmland or farm and residential buildings to be sold or rented out by farmers.

This strategy is easier to implement in the Mediterranean hinterland highlands because of the long-lasting rural exodus. Abandoned land can be farmed again, under alternative, less mechanized, farming styles. In our study area, some market gardeners created their farms on cleared wasteland on river banks. Some livestock farmers re-used former farming terraces on slopes and rangelands on plateaus. But already farmed parcels are also an integral part of the non-sharing strategy: in the most remote areas, for example, some retiring farmers have trouble finding successors, which affords new opportunities for aspiring farmers without any agricultural background.

\footnotetext{
${ }^{11}$ Our own translation, from "laboratoire foncier".

12 "Land of Links"

${ }^{13}$ Association pour le développement de l'emploi agricole et rural, Association for the development of farming and rural jobs

${ }^{14}$ Our own translation, from «petites fermes, tournées vers l'économie locale et le respect de l'environnement. [...] mise en place d'une agriculture plus autonome, créatrice d'emploi, et productrice de biens et de services de qualité. » (http://www.jeminstallepaysan.org/addear12)
} 


\section{Conclusion}

This article identified the need to better understand the local practices operating in parallel with national land management regimes. To do so, we used the notion of "farmland management style", encompassing the organization of access to the land for farmers and the formalized relationships between owners and users. We applied it to a French Mediterranean highland, the northern Larzac, using a diachronic bundle-of-rights analysis. We showed that in this region several collective and public alternative management styles are applied by (de jure or de facto) farmers' organizations or by local authorities. Within space-sharing strategies creating farmland estates, their implementation can promote local short food supply chains more successfully than the mainstream style does. They achieved this by targeting a specific farming style (e.g. organic market gardening for school canteens for the Millau Grands Causses local authority) and the aspiring farmers undertaking it. These alternative management styles can also be used to secure the tenure of a group of alternative farmers (which is what SCTL and SC GFA Larzac do). Other "non space-sharing" strategies are also being implemented in parallel, by coaching aspiring alternative farmers on how to access land on the private market managed by the mainstream style. Space-sharing and non space-sharing strategies should be conceived as complementary.

Thus, public and collective land strategies are helping to meet the current demand for local food. National decision-makers could learn from such local practices, using them to reform the mainstream management style and open it more to civil society. One lever could be to include associations and/or NGOs involved in food issues in the local committees that allocate land exclusion/inclusion rights. This is what the French « Rural Christian Youth Movement » and a group of 25 civil society organizations propose. They (i) advocate for the creation of Local Land Councils composed of farmers, members of local councils, citizens and landowners (Commission foncier du MRJC, 2010) and (ii) ask the government "to open to civil-society organizations decision-making bodies responsible for the agricultural and food policies" (Confédération paysanne et al., 2017). Local decision-makers in villages could also take back control of the commons, thereby redirecting large tracts of public farmland mainly managed under the mainstream style to management styles favoring local food supply. Finally, national and local decision-makers could consider allocating funds for the acquisition of land by local authorities to support local food supply projects. Their management could be public or collective (e.g. through agreements with the Terre de Liens investment company and endowment land trust). To the objection that the financial means of public bodies are limited, it can be replied that total annual sales on the French farmland market represent no more than $0.6 \%$ of state and local authorities' budgets. As the history of the Larzac proves, the Mediterranean highlands are an appropriate setting for the introduction of alternative FMSs, because of their long-standing rural exodus. Further research could usefully explore how such local experiments can be extended to a larger - regional or national - scale.

\section{Acknowledgements}

Funding: this work was supported by the French National Research Agency [ANR JASMINN $\mathrm{n}^{\circ}$ ANR-14-CE18-0001]. 
We sincerely thank all reviewers, whose precise and very accurate comments truly helped us sharpen the analysis and improve the article.

\section{References}

Bauerkämper A., Iordachi C. (ed.) (2014), The Collectivization of Agriculture in Communist Eastern Europe. Comparison and Entanglements, Budapest, CEU Press, ISBN 978-615-5225-63-5

Baxter J. (2013), "Legal institutions of farmland succession: implications for sustainable food systems", Maine Law Review, 65(2): 382-408.

Baysse-Lainé A., Perrrin C. (2017), «Les espaces agricoles des circuits de proximité : une lecture critique de la relocalisation de l'approvisionnement alimentaire de Millau » [Farmland of local supply chains: a critical reading of food relocalisation in Millau, France], Nature Sciences Sociétés, 25(1): 21-35.

Boinon J.-P. (2011), « Les politiques foncières agricoles en France depuis 1945 » [Farmland policies in France since 1945], Économie et statistiques, 445-446: 19-37

Borras S. M. Jr., Franco J. C. (2012), "Global Land Grabbing and Trajectories of Agrarian Change: A preliminary Analysis", Journal of Agrarian Change, 12(1): 34-59

Brown K. M. (2006), "New challenges for old commons: The role of historical common land in contemporary rural spaces", Scottish Geographical Journal, 122: 109-129. doi:10.1080/00369220600917412

Bruce J. (2000), "African tenure models at the turn of the century: individual property models and common property models", Land Reform, Land Settlement and Cooperatives, 2000/1: 1-27

Clément C., Soulard C. (2016), «La publicisation des espaces agricoles périurbains dans le Lunellois, Languedoc. Un cadre d'analyse en géographie» [The Peri-urban Farmland Publicization: A Multiscale Framework], Annales de géographie, 712: 590-614

Commission Foncier du MRJC (2010), De la gestion de l'espace à l'accès à la terre, le foncier : une problématique $d u$ développement rural et agricole [From space management to access to the land: the land as an issue for rural and agricultural development], Mouvement rural de jeunesse chrétienne, Pantin.

Confédération paysanne et al. (2017), Treize doléances pour l'accès de tous et toutes à une alimentation de qualité, produite par des paysannes et paysans qui vivent de leur travail et pratiquent une agriculture paysanne [Thirteen grievances for the access of everyone to a quality food, produced by peasants making a living from their work and farming on small-scale and peasants farms], Agriculture and Food Campaign Produce at what price, eat at what price ?, Bagnolet

Cooper O. (2013), “County council farm tenancies: still an option?", Farmers Weekly, September $19^{\text {th }}$, http://www.fwi.co.uk/business/county-council-farm-tenancies-still-an-option.htm

Coulomb P. (1999), «La politique foncière agricole en France » [Farmland policy in France], Cahiers Options Méditerranéennes, 36: 69-94

Courleux F. (2011) «Augmentation de la part des terres agricoles en location : échec ou réussite de la politique foncière? » [Does the rising share of rented farmland means farmland policy succeeded or failed?], Économie et statistique, 444-445: 39-53.

Fay D. (2009), "Land Tenure, Land Use, and Land Reform at Dwesa-Cwebe, South Africa: Local Transformations and the Limits of the State", World Development, 37(8): 1424-1433

Frayssignes J. (2011), "System IV: Roquefort cheese”, p. 177-183 in Barham E., Sylvander B., Labels of origin for food. Local Development, Global Recogntion, CABI, 218 p.

Hoffman M. (2013), "Why community ownership? Understanding land reform in Scotland”, Land Use Policy, 31: 289-297.

Holden S. T., Ghebru H. (2016), "Land tenure reforms, tenure security and food security in poor agrarian economies: Causal linkages and research gaps", Global Food Security, 10: 21-28 
Kremer P., DeLiberty T. (2011), "Local food practices and growing potential: the case of Philadelphia", Applied Geography, 31(4): 1252-1261

Lasanta T., Arnaez J., Pascual N., Ruiz-Flaño P., Errea M. P., Lana-Renault N. (2017), "Space-time process and drivers of land abandonment in Europe", CATENA, 149(3): 810-823

Lavigne Delville P. (2010), « Tenure security, formalization of rights, land regulation institutions and investments. For a broader conceptual framework », Land Tenure Journal, 1: 5-33

Le Monnier J. (2013), « Terre de Liens : histoire de convergences » [Land of Links: A story of convergences], Pour, 220: $289-296$.

Luning H. (1984), "Impact of land tenure on land use in low-income countries", Land Use Policy, 1(2): 112-124

Maxwell D., Wiebe K. (1999), “Land Tenure and Food Security: Exploring Dynamic Linkages”, Development and Change, 30(4): 825-849.

Merten S., Haller T. (2008), "Property rights, food security and child growth: Dynamics of insecurity in the Kafue Flats of Zambia”, Food Policy, 33(5): 434-443

Millar J., Roots J. (2012), « Changes in Australian agriculture and land use: implications for future food security », International Journal of Agricultural Sustainability, 10(1)

Moreau J.-C. (1981), “Evolution de l'utilisation agricole du territoire de deux communes du Larzac : Ste-Eulalie de Cernon - St-Michel » [Evolution of the agricultural land use of two villages of the Larzac: Sainte-Eulalie de Cernon and Saint-Michel], ingeneer thesis in agronomy, ESA Purpan

Pibou E. (2017) « De la gestion collective du foncier agricole au bien commun : processus de requalification des statuts de la terre » [From collective farmland management to common good: processes of land statuses' requalification], Études rurales, 199, in press

Pisani E. (1977), Utopie foncière. L'espace pour l'homme [Land Utopia. The space for the man], Gallimard, 232 p.

Ploeg J. D. van der, Laurent C., Blondeau F., Bonnafous P. (2009), "Farm diversity, classification schemes and multifunctionality", Journal of Environmental Management, 90(2): 124-131

Ploeg J. D. van der, Franco. J. C., Borras S. M. (2015), "Land concentration and land grabbing in Europe: a preliminary analysis", Canadian Journal of Development Studies / Revue canadienne d'études du développement, 36(2): 147-162.

Pluvinage J., Guiomar X., Rosenwald V., Boinon J.-P. (ed.) (2013), «Le foncier : lieux de tensions et bien commun » [Land: a place of tensions and a common good], Pour, 220: 1-350

Quetier, F., Marty, P., Lepart, J. (2005), “Farmer's management strategies and land use in an agropastoral landscape: roquefort cheese production rules as a driver of change", Agricultural Systems, 84: 171-193.

Rialland-Juin C. (2016), «Le conflit de Notre-Dame-des-Landes : les terres agricoles, entre réalités agraires et utopies foncières » [Farmland and the Notre-Dame-des-Landes conflict: From utopian ownership models to agricultural realities], Norois, 238-239: 133-145. DOI: 10.4000/norois.5907

Richani N. (2012), “The Agrarian Rentier Political Economy: Land Concentration and Food Insecurity in Colombia", Latin American research Review, 47(2): 51-78.

Rockson G., Bennett R., Groenendijk L. (2013), "Land administration for food security: A research synthesis", Land Use Policy, 32: 337-342.

Rudbeck Jepsen, M. et al. [48 co-authors] (2015). "Transitions in European land-management regimes between 1800 and 2010", Land Use Policy, 49: 53-64

Schlager E., Ostrom E. (1992), "Property-Rights Regimes and Natural Resources: A Conceptual Analysis", Land Economics, 68(3): 249-262

Selfa T., Quazi J. (2005), "Place, taste or face-to-face? Understanding producer-consumer networks in 'local' food systems in Washington State", Agriculture and Human Values, 22(4): 451-464

Sencébé Y., Pinton F., Alphandéry P. (2013), « Le contrôle des terres agricoles en France. Du gouvernement par les pairs à l'action des experts » [The control of farmlands in France. From peer-management to management by experts], Sociologie, 4(3): 251-26

Souder J. A., Fairfax S. K. (1996), State trust lands: history, management and sustainable use, University Press of Kansas, Lawrence. 
Spalding A. K. (2017), "Exploring the evolution of land tenure and land use change in Panama: Linking land policy with development outcomes", Land Use Policy, 61: 543-552.

Terral P.-M. (2011), Larzac : de la lutte paysanne à l'altermondialisme [Larzac: from the peasants' struggle to the alterglobalization], Privat, Toulouse.

Vivier N. (1998), Propriété collective et identité communale : les biens communaux en France, 1750-1914 [Collective property and municipal identity: common lands in France], Publications de la Sorbonne, $352 \mathrm{p}$.

Wright J. B. (1992), « Land trusts in the USA », Land Use Policy, 2(9): 83-86. 